\title{
GREEN ECONOMY: GLOBAL DEVELOPMENT PRIORITIES
}

\author{
Gyunduz Mamedov', Nadiia Babych²
}

\begin{abstract}
The aim of the article is to reveal the modern priority trends in forming incentives for the world green economy development in the context of globalization. The subject of the study is the global priorities for green economy development. Methodology. The scientific literature analysis enables to study the current economic status of the global green economy and to determine strategic priorities and targets of such development, in addition, the dialectical method, scientific abstractions, methods of system analysis are used. The results of the study reveal that the authors propose a perspective on the strategy, ways and mechanisms of the global green economy development. It is proven that a complex structural transformation of the economy is required to increase the share of the high-tech and innovative sectors. Practical implications. The complex analysis of the state of affairs and determining trends in the green economy development under threats and risks, related to the crisis processes in the modern world, is carried out. The study determines the key principles for the formation and implementation of a strategy for the green economy development based on the coherence of strategic priorities and strategic targets of the EU, as well as the need to reform the economic sector in order to develop promising green economy areas in Ukraine. Relevance/originality. The study reveals the state of affairs in the global green economy development, as well as further identification of promising trends of the green economy.
\end{abstract}

Key words: green economy, economic development, innovative development, ways of improvement.

JEL Classification: F63, R11

\section{Problem statement}

Current changes in society lead to occurrence of both positive and individual negative trends, which significantly impede the development of the world economy and cause serious problems of economic stability (Mohilevskyi, Sevruk, Pavlenko, 2017) in the world. The 21st century should be decisive in the history of humankind, because there is no alternative to balancing the man-made impact on the environment with the ability to reproduce the primary properties of natural components, to developing without the deterioration in living conditions of organisms. The development of society in the 21 st century will be based mainly on innovation, new technologies and elaboration of information flows that is why it requires new approaches to the use of natural resource potential (NRP) (Filipenko, Budkin, Halchynskyi, 2002).

Current changes in society lead to occurrence of certain both positive and negative trends, which significantly impede the development of the world economy and cause serious problems of economic stability (Mohilevskyi, Sevruk, Pavlenko, 2017) in the world. Numerous examples demonstrate that economic development, high competitiveness and productivity

\footnotetext{
Corresponding author:

${ }^{1}$ General Prosecutor's Office of Ukraine, Ukraine.

E-mail: MamedovH@ukr.net

${ }^{2}$ Taras Shevchenko National University of Kyiv, Ukraine.

E-mail: Babych_NO@gmail.com
}

in the information economy (as opposed to industrial) is not possible without permanent accumulation of new knowledge and effective work with relevant information. It should be noted that the interrelation between intellectual activity and material production has become especially close due to the development of information and communication technologies that have enabled a person to continuously generate and accumulate new layers of knowledge and information (Pestova, 2014).

The global problems of humankind, such as climate change, resource depletion, poverty, overpopulation, and food shortages, are compounded by the crisis of a socio-economic system built on free market relations. Market self-regulation processes have a negative impact on social security and the environment. Therefore, the UN experts advise to concentrate on the formation of a new green economy, which provides for an increasing role for the State and interstate bodies in economic regulation, promotion of business development on the basis of new green technologies and greening of industrial branches of economy. This study focuses on the issue of strategic priorities for the green economy development in the context of economic security (Hrytsiuk, Vasylenko). 
The aim of the article is to reveal the modern priority trends in forming incentives for the world green economy development in the context of globalization.

\section{Main material}

The formation of the green economy is a modern trend of ensuring the economic security of the State in the context of globalization. Poverty eradication, control over the use of natural resources, and increase in the number of jobs should be under focus. Application of market mechanisms should be combined with national and international regulation of economic processes. Improving the environmental situation ceases to be an expenditure line of the State budget and becomes the very essence of the new economic system. Therefore, the State forms new economic conditions for doing business, attractive for investments precisely in the development of new green industries and ecological transformation (greening) of the traditional economy (Hrytsiuk, Vasylenko).

The 2009 Nobel Prize winner in Economics, Paul Krugman, argues that there is no reason to believe that free markets will deliver an outcome that society considers fair. Market efficiency is in no way related to the guarantee of health insurance, aid to the poor, etc. Markets should be allowed to do their job, making efficient use of the nation's resources, then taxes and transfers should be utilized to help the poor. When there are "negative externalities", that is, costs that economic actors impose on others without paying an adequate price for environmental pollution and the use of natural resources, any presumption that the market economy will self-regulate, does not work. The green economy answers these questions (Krugman, 2010).

Green growth means fostering economic growth and development, while ensuring that natural assets continue to provide the resources and environmental services on which our well-being relies. To this end, it must catalyse investment and innovation that will be a basis for sustainable growth and contribute to new economic opportunities (Kurs na zelenyiy rost).

According to the US Social Investment Forum, about $11 \%$ of big corporations spend on sustainable investing; in Europe, this figure is about $17 \%$. Nowadays, most grants from international organizations are given under fairly stringent environmental terms, which increases the interest of businessmen in the development of green technologies (Strategiya "Zelenogo" zrostannya OESR).

Officially, the OECD Green Economy policy was adopted in 2009 as a strategic direction for development (OECD Green Growth Strategy) (Organization for economic co-operation...). In Europe, the official document for this is the Roadmap to a ResourceEfficient Green Economy in Europe. In addition, Low Carbon Green Growth Roadmap for Asia and the Pacific is adopted (European Commssion).
The goal of the green economy is to create an effective environment for economic and social progress, based on minimizing the negative impact on the environment and the efficient use of natural resources while maintaining a decent standard of living. This goal is achieved through lower goals (sub-goals), which include protection, conservation, reproduction of natural resources and prevention of nonrecoverable losses of biodiversity by minimizing negative anthropogenic impact on the environment, conservation and restoration of green spaces, ensuring the integrity of ecosystems, improving the quality of natural resources, etc.; increase of resource efficiency (increase of productivity of natural resources involved in economic circulation and reduction of waste volume through implementation of the closed loop production and maximum waste utilization), with reorientation to the preferential use of renewable resources; economic development based on structural changes leading to an increased importance of green sectors with a corresponding reduction in brown ones; ensuring social progress in the green segment of the economy, that is, creating "green" jobs, increasing the income generated by employment in the "green" sector of the economy, improving the quality of goods and services by entering the "green" market, etc. (Chmyr, Zakharkevych, 2013).

In this study, Ukraine should be under focus due to its great potential for green economy development, but unfortunately, to some extent, it does not properly use natural resources to ensure economic growth and sustainability.

At the present stage, Ukraine, as a European State, implement a set of strategic measures aimed at developing the economy in the context of the European integration (Yunin, Sevruk, Pavlenko, 2018). Therefore, Ukraine's economic development requires today, as never before, a well-targeted and sound macroeconomic policy aimed at further stabilization. Since the radical socio-economic transformations over the last decade have caused both positive and negative changes in Ukrainian society (Pavlenko, Sevruk, Kobko, 2017).

The system of economic security of Ukraine's development in the context of globalization requires consideration of the current trends of world development. It is about introducing the principles of green economy into different sectors of our country's economy. From the perspective of ensuring the economic security of the State, it is possible to distinguish new green sectors of the economy, as well as those that undergo environmental transformation (greening) of the existing branches of the Ukrainian economy.

Energy security:

- small hydropower;

- wind power;

- solar electric power;

- biogas energy; 
- the use of combustible gases from coal and lignite conversion process;

- providing power plants with cleaning equipment;

- refusal of direct combustion of coal;

- utilization of secondary energy resources, such as woodworking and other waste.

Resource security:

- transition to utilization of local energy sources, such as peat, firewood, shale, with modern environmentally friendly technologies;

- use of shale gas.

Food Security:

- control over the cultivation, production, sale and consumption of GMO products;

- introduction of eco-labelling;

- development of organic agriculture.

Social Security:

- adaptation of the economy and population to climate change;

- improving the energy efficiency of housing;

- systematic measures to prevent man-made emergencies.

Industrial safety:

- green building, the widespread use of energy-saving technologies and materials produced with minimal environmental damage;

- development of green tourism;

- energy savings in production;

- implementation of the "cleaner production" program;

- application of green technologies;

- joint implementation projects under the Kyoto

Economic Mechanism.

Transportation Security:

- development of green transport, such as trolleybuses, trams, electric cars, bicycles;

- limitation of emissions from motor vehicles, air transport.

Financial security:

- formation of the carbon market;

- green purchases;

- Green electricity tariffs.

Regional Security:

- rehabilitation of territories affected by radioactive contamination resulting from the Chernobyl disaster;

- reduction of water consumption;

- restoration of forests and protected areas (Potapenko, 2012).

The annual turnover of the green economy in the EU is over $€ 300$ billion, equivalent to $2.5 \%$ of GDP. It already employs about 3.4 million people, i.e. $1.5 \%$ of all employed. A quarter of all investment goes to clean technologies. For example, a wind power trend gives the largest increase in investment compared to other sectors of the EU economy in recent years.

Evidently, it is time to formulate a strategy for the development of the Ukrainian economy on an innovative basis and to adopt relevant legislation, using the experience developed and implemented in many countries of the world, such as the USA and the European Union, including Great Britain, Germany, Poland (Heiets, 2015). Therefore, the current legislative framework governing innovation activity in Ukraine should be analysed thoroughly to introduce effective proposals on changing this framework, taking into account the challenges of economy modernization on an innovative basis. Thus, fulfilment of these missions requires "transition of the national economy to the "green" model of development based on sustainable production and consumption, decoupling of economic growth and implementation of measures on combating degradation of the environment and exhaustion of natural resources and implementation of green growth policies based on the effective use of material resources, as well as the results of scientific research and environmentally-oriented innovative technologies, promotion of business activities in resource-efficient and environmentally safe production" (Yunin, Sevruk, Pavlenko, 2018; Drozd, Pavlenko, Sevruk, 2019).

In September 2015, the United Nations adopted a new global program to ensure a sustainable future by 2030, which sets out 17 Sustainable Development Goals (hereinafter referred to as the SDGs) and 169 targets. SDGs should become a platform for developing national strategies for over the next 15 years. It is Goal \# 8 that promotes progressive, inclusive and sustainable economic growth, full and productive employment and decent work for all.

The Organisation for Economic Co-operation and Development (OECP) projections suggest that with current production and consumption by 2050, the world will lose two-thirds (61 to $72 \%$ ) of flora and fauna compared to the beginning of the 21st century, and the conservation of natural areas will be irreversibly impaired in 7500 thousand square kilometres, this is comparable to the territory of Australia (Policy Brief).

For the European Union specialists, sustainable development is a complex construction, which involves balanced development of three components, such as economic, social and environmental. Therefore, sustainable development cannot be referred from the perspective of only one component. Schematically sustainable development can be presented as the intersection of three circles: economy, society, nature. Thus, the place of their intersection will become an area of sustainable development. Unfortunately, in the world and in Ukraine these are three equal circles now. Nowadays, the economy is the largest circle, society is a smaller circle, and nature is the smallest circle, which is almost out of focus for the economy and society. And the challenge of sustainable development is to make these circles equal and to make the maximum area of their intersection balanced. One of the keys for systematic and coherent activity of the country in the course of introducing the concept of sustainable development is 
the development of a comprehensive plan of actions, strategies that would ensure the full implementation of economic entities' activities without discrimination of environmental and social interests; would consider the international experience of implementing the above concept and the reality of the entire world economy. In turn, the multifaceted notion of sustainable development and differences in mentality, culture of the peoples of the world determine the presence in the scientific literature of a wide range of individual approaches of economists and collective views, formulated within international organizations, concerning the interpretation of the essence, components of such documents and, above all, sustainable development strategies (Ianshyna, 2014; Makovoz, Perederii, 2018).

\section{Conclusions}

Therefore, at the presentstage, thebasisforthesuccessful development of countries is the implementation of public policies aimed at economic growth in accordance with the latest global trends of sustainable development, such as the model of green economy. The green economy model deepens and develops the concept of sustainable socio-economic development. It has occurred to address the challenges of today, related to natural capital degradation, increase in world poverty, acceleration of the onset and magnitude of the global crises. According to UNEP, there is no one-size-fits-all solution to the transition to the green economy. All measures should relate to the characteristics and natural heritage of each country, the level of its development, the effectiveness of its institutions, as well as the nature and extent of prevailing defects in the market mechanism, sectors identified as priorities, targets and other specific factors in an individual situation. It must be acknowledged that the transition to the green economy promises numerous benefits for the international community and all nations in terms of addressing food, energy and water security and climate change. This model is considered as an effective response to the financial crisis, which can ultimately lead to the achievement of the Millennium Development Goals. At the same time, further study of the green economy, in particular with regard to developing and transitional economies, needs to be continued (Hrytsiuk, Vasylenko).

Therefore, the green growth doctrine is considered as a system of long-term actions, itemising resource opportunities, justifying the importance of green growth of the Ukrainian economy and favourable business environment at both national and regional levels. This doctrine is based on the analysis of opportunities to use available natural resources more effectively on the principles of interregional (transnational) cooperation and mutual compensation for the damage caused. The implementation of these measures should form a sustainable economic system focused on providing a green vector for the development of the economy of the country and its regions. In practice, a scientific interpretation of favourable institutional prerequisites that ensure the implementation of the Ukrainian green economy doctrine requires further improvement and innovative ways of its development should be substantiated (Halushkina, 2011).

\section{References:}

Mohilevskyi, L. V., Sevruk, V. G., \& Pavlenko, S. O. (2017). Psycho-Pedagogical Training of Operating Unit Workers of National Police of Ukraine. Nauka i osvita, no. 11, pp. 120-132.

Filipenko, A. S., Budkin, V. S., Halchynskyi, A. S. ta in. (2002). Ukraina i svitove hospodarstvo: vzaiemodiia na mezhi tysiacholit [Ukraine and the world economy: interaction at the turn of the millennium]. Kyiv: Lybid, 470 p. Mohilevskyi, L. V., Sevruk, V. G., \& Pavlenko, S. O. (2017). Psycho-Pedagogical Training of Operating Unit Workers of National Police of Ukraine. Nauka i osvita, no. 11, pp. 120-132.

Pestova, T. M. (2014). Dosvid zarubizhnykh krain shchodo stanovlennia ta funktsionuvannia intelektualnoi pratsi, kapitalu ta vlasnosti v umovakh stanovlennia ekonomiky postindustrialnoho typu [Experience of foreign countries on the formation and functioning of intellectual labor, capital and property in the conditions of post-industrial economy]. Efektyvna ekonomika, no. 3. URL: http://nbuv.gov.ua/UJRN/efek_2014_3_78

Hrytsiuk, T. I., \& Vasylenko, T. V. Stratehichni priorytety rozvytku «zelenoi ekonomiky» v krainakh svitu [Strategic priorities for green economy development in the countries of the world]. URL: http://www.economy.nayka.com.ua/ ?op $=1 \& z=3081$

Krugman, P. (2010). Building a Green Economy. URL: http://www.nytimes.com/2010/04/11/ magazine/11Economy-t.html?pagewanted=all

Kurs na zelenyiy rost. Rezyume dlya lits, prinimayuschih resheniya [Heading for green growth. Resume for decision makers]. URL: http://www.oecd.org/greegrowth/48634082.pdf

Strategiya “Zelenogo" zrostannya OESR [The strategy of "green” growth OECD]. URL: http://www.oecd.org/ greengrowth

Organization for economic co-operation and development Declaration on Green Growth, adopted at the Meeting of the Council at Ministerial Level on 25 June 2009. [C/MIN(2009)5/ADD1/FINAL]. URL: www.oecd.org/ env/44077822.pdf

European Commssion. Europe 2020: a European strategy for smart, sustainable and inclusive growth. Brussels, COM(2010) 2020. URL: http://europa.eu/press_room/pdf 
Chmyr, O. S., \& Zakharkevych, N. P. (2013). «Zelena» ekonomika: sutnist, tsili ta bazovi pryntsypy [Green economy: the essence, goals and basic principles]. Ekonomichnyi visnyk Donbasu, no. 3(33), pp. 54-62.

Yunin, O., Sevruk, V., \& Pavlenko, S. (2018). Priorities of economic development of Ukraine in the context of european integration. Baltic Journal of Economic Studies, vol. 4, no. 3, pp. 358-365. doi: 10.30525/2256-0742/20184-3-358-365

Pavlenko, S. O., Sevruk, V. G., \& Kobko, Ye. V. (2017). Training police officers in the conditions of reforming the system of education of the Ministry of Internal Affairs of Ukraine in accordance with European standards. Nauka i osvita, no. 6, pp. 142-150.

Potapenko, V. H. (2012). «Zelena» ekonomika v systemi stratehichnykh priorytetiv bezpechnoho rozvytku Ukrainy [Green economy in the system of strategic priorities for the safe development of Ukraine]. Ekonomichnyi chasopys-XXI, no. 3-4, pp. 9-11.

Heiets, V. M. (ed.) (2015). Innovatsiina Ukraina 2020: natsionalna dopovid [Innovative Ukraine 2020: a national report]. NAN Ukrainy. Kyiv, 336 p.

Drozd, O., Pavlenko, S., \& Sevruk, V. (2019). Theoretical and legal analysis of foreign experience on illegal amber production: Environmental and economic aspects. Asia Life Sciences, Issue 2, December, pp. 1-19.

Policy Brief: Achieving Energy Security in Developing Countries. GNESD, 2010.

Ianshyna, A. M. (2014). Instytutsiina skladova implementatsii kontseptsii staloho rozvytku u krainakh Pivnichnoi Yevropy [Institutional component of the implementation of the sustainable development concept in Northern Europe]. Aktualni problemy mizhnarodnykh vidnosyn, no. 118(1), pp. 172-182.

Makovoz, O. S., \& Perederii, T. S. (2018). Zelena ekonomika yak zaporuka staloho rozvytku [Green economy as a pledge for sustainable development]. Yevropeiskyi vektor modernizatsii ekonomiky: kreatyvnist, prozorist ta stalyi rozvytok: monohrafiia. L. L. Kalinichenko (ed.). Kharkiv: FOP Panov A.M., pp. 159-168.

Hrytsiuk, T. I., \& Vasylenko, T. V. Stratehichni priorytety rozvytku «zelenoi ekonomiky» v krainakh svitu [Strategic priorities for green economy development in the countries of the world]. URL: http://www.economy.nayka.com.ua/ ?op $=1 \& z=3081$

Halushkina, T. (2011). "Zelenyi" vektor rozvytku ekonomiky Ukrainy ["Green" vector of economic development of Ukraine]. Ekonomist, no. 11, pp. 4-7. 